\title{
THE TRAMP PROBLEM
}

\author{
By O. F. Lewis,
}

General Secretary, Prison Association of New York.

What we in the United States need to do first with the tramp problem is to wake up. We have dealt with it too long as we do with a disagreeable visit to the dentist, that ought to be paid but is not.

We have a rural tramp problem and a city vagrancy problem. Let us first take up the general question. Tramps don't tramp very much; they ride. The railroads are the best and the worst friends of the tramps; best, because, as Josiah Flynt has said, they enable the man who begs from you on the streets of New York on Monday to accost you on the streets of Chicago on Saturday; worst, because the railroads are the severest prosecutors of the tramps.

The tramp problem is both easy and hard to understand. Easy, because it is easy to understand what makes tramps; hard, because it is hard to know how to deal with the products of the causes, or with the causes themselves. Because it is easy to get rid of an individual tramp, and so hard to handle rationally a group of tramps, the almost overpowering tendencies of individuals and communities are to do as the man did with the dead cat:-throw it into his neighbor's yard, from which it, in turn, progressed through other yards until it arrived again in the yard of the original neighbor.

There is much unclear thinking about tramps. The bulk of people probably do not know what they mean when they talk about tramps. Some of them have learned about tramps from funny papers; some from the stranger in the street; some from having their summer cottages robbed or burned; some from being on boards of managers of hospitals that give costly free treatment to worthless outcasts. Charitable societies, missions, city lodging houses, courts and prisons have all dealt with, and do deal with, the "hobo." When the solution of a problem is hard and costly and perhaps useless in the end, it is apt to be side-tracked. Thus it is with the related problems of inebriety and vagrancy. 
Yet in the United States census of 1904 it was shown that drunkenness ranked first among the causes of commitment to penal institutions in the United States, and that vagrancy ranked second. Between them they caused 43 per cent of the commitments in the year 1904. That is a costly price to pay for neglect to solve, if possible, the problems of drink and voluntary idleness.

I do not wish to lead the readers of this journal again through the array of well-known or widely announced facts and opinions regarding the extent, the costliness and the futility of vagrancy and the tramp-evil. Since we are a nation of newspaper readers, it must be familiar news to us that the railroads report that in the aggregate they lose at least $\$ 25,000,000$ a year through railroad vagrancy; that there are perhaps a half million tramps in the United States; that their paths lead like cow tracks all over their rich pastures, the states of the Union; that they are in general a most unproductive and most disagreeable group; that they cost charitable and correctional institutions and organizations millions a year to take care of them; that they corrupt the young and rob the older; that they disseminate disease, perpetrate and encourage crime, and maintain indecent standards of living.

I would point out, first, some movements toward a reduction of vagrancy, and secondly, some vitally necessary things that have not yet been undertaken. First and foremost, we must deal with the tramp-evil along broad and national lines, probably not by fedcral laws, but through state laws and with the keen sense of the national character of the problem. Our methods must be tested, not primarily by the question whether they will rid the particular community of tramps, but whether they will, when adopted in general by other communities, tend successfully to reduce vagrancy and its attendant evils.

First then, I cite the agitation for farm colonies for tramps and vagrants. New York State established, in I9I I, a board of managers of such a compulsory farm colony, "for the detention, humane discipline, instruction and reformation of male adults committed thereto as tramps and vagrants." This is an experiment, brought to its present stage by a strong group of social workers in New York who have become sick and tired of the palliative and trivial treatment of the tramp-evil in the past. The colony will have not less than five hundred acres; will be probably from fifty 
to one hundred miles from New York City; will receive persons on indeterminate sentences of a maximum of eighteen months, except such as since arriving at the age of sixteen have been conmitted to a penal institution. The colony will probably be largely upon the cottage plan, and will maintain a system of marks and merits, privileges and deprivations, and a system of parole.

What will be the result? Prophesy is dangerous. It is believed that the best weapon with which to fight vagrancy is compulsory work, just as there is nothing like water with which to fight a large fire, although chemicals may suffice with small blazes. Wherever work is announced at workhouses, jails, almshouses and other institutions and organizations, the attendance of the loafing vagrant falls off. Wherever in cities the mendicancy squads are active and persistent, the city is to an extent relieved of the influx of the panhandler and the whining, shuffling man who has work to go to on Monday.

The farm colony will combine compulsory work with a long enough term of imprisonment, even under restricted liberty, to make the predatory vagrant careful about travelling through the state or seeming to be for a considerable time without employment. And I would say here that the law expressly states that the colony is not meant for "reputable workmen, temporarily out of work and seeking employment." The courts will be notified by the board of managers of the colony, when it is ready to receive inmates, that the colony is meant not for those tramps who can be readily swung back into industrial life and self-support, but for those "customers," as the Germans call them, who have purposely and persistently defied the efforts of the law and of the community to make them decent citizens.

Hence, it is reasonable to expect that the total number of vagrants in the state will be reduced. "But," says the inhabitant of New Jersey, "you are simply throwing the tramps into New Jersey and Connecticut." True; but the advice of New York will be that both New Jersey and Connecticut establish farm colonies. Then, in two ways, the deterrent influence of the colony will be more or less potent. For those who pass through the colony, the idea of giving another year or more to the service of the state at lard work, if again convicted of vagrancy, will not be agreeable. For those who have shunned the colony by staying in another state, the deterrent effect of the New York colony is obvious. 
In short, the farm colony is simply typical of what in general the method must be of counteracting vagrancy. The tramp is the most volatile of all dependents or delinquents. Pages of proof can be presented of this fact, and perhaps most striking of all would be the facts gathered from juvenile institutions.

Will the colonies reform the shiftless, work-shy tramp? Probably not to any great extent. In individual cases, yes. But I am firmly of the opinion that to reduce vagrancy we need to employ strong and persistent corrective measures. I have this last summer visited the leading labor colonies of Belgium, Holland and Germany. Everywhere the testimony is the same, although some of the colonies have been in existence nearly one hundred years. The vagrant on the other side of the water is, in four cases out of five, a repeater, not permanently reclaimable. The great service rendered by foreign compulsory labor colonies is that they act as segregating centers for the half-efficient and intentionally idle, and as a deterrent for those who can foresee that a life of vagrancy will mean frequent compulsory segregation in the colonies. The European countries would not think of giving up the forced labor colonies, but they do not make claims that they are reformatories. We in the United States must not allow ourselves to hail the new farm colonies as reformatories or as strong factors in the elimination of the tramp. I have no belief at all that the tramp can be eliminated so long as the world takes summer vacations, and rich people follow their bent and go to Florida in the winter, and so long as Cook's tours find a justification for being. The tramp has the same desires, but not the same means. Being without means, he tramps, or, as I have aready said, he rides.

This leads to the second point. We must bend our best energies to the reduction of railway trespass. I believe no one wishes this reduction so much as the railways themselves, for they are the chief sufferers. Where the individual community suffers somewhat, the long trunk lines suffer grievously. Apart ftom the hundreds of thousands of dollars lost by our great railways, the lives of trainmen are frequently imperilled. A state of warfare exists between the trainmen in general and the tramps in general, although exceptions to the "state of war" exist, of course.

What are the results of railway trespass? First, the loss to the railroads in property destroyed, stations burned, obstructions 
placed on tracks, signals tampered with, lives lost, persons injured -and, indeed, the not infrequent suits that are brought by tramps themselves for injuries sustained while riding, or while walking on the railroad.

Then also the cost to the community. Railroads will literally "dump" a group of tramps upon a village or a town. The village reasons with justice that since the railroad gives, therefore let the railroad take away, and is frequently known to load the tramps upon the next freight. Or the justice of the peace or the police court judge suspends sentence on condition that the tramp betake himself to the next settlement, where the next judge may still further pass him along, or send him to the local jail.

How can railway vagrancy be reduced? By making the cost of maintenance of vagrants and tramps in correctional institutions a state charge. Just as long as the local authorities have to stand the expense of the imprisonment period of tramps and vagrants, just so long will the passing-on system continue. Railroad detectives may work twenty-four hours a day, only to have the local court release or speed the parting plague on the twenty-fifth hour, because the town cannot afford to stand the expense.

This movement requires legislative action. Such action must be impelled by a strong force. I believe that a national vagrancy committee is a necessary organization. The railroads should be large factors in supporting it financially. Their gain in the reduction of railway vagrancy would be the communities' gain. Therefore, the communities should uphold the railroads in fighting vagrancy, and not look upon their efforts as another example of the persecutions of a soulless group of corporations.

In the third place, almshouses should not be used as the abode or resting-up place for able-bodied workshys. In the absence of "tramp houses" with worktests, one cannot blame the timid farmer's wife from quickly bolting the door and shouting through the crack of the door to the rural tramp to go to the poorhouse over night. That raises two questions. First, will the community establish a tramp house with a work test? Secondly, does not the farmer's wife run a real danger in refusing the tramp food or shelter? Answering the second question first, I would say that the testimony of tramps with whom I have talked is, that the tramp, if not sustaining violence, is not liable to wreak any physical revenge for 
not receiving aid. It is a battle of wits. The tramp is generally lying as to his need. He has little admiration for the gullible housekeeper. If refused, he says to himself: "She didn't fall for my yarn." I have lived several years in the suburbs of New York on a farm, and commuted to my work in New York. We have refused many tramps, or offered them work, and we have never suffered any physical harm.

Furthermore, the more violence that there might be, the stronger is the argument for bringing about a change in the present ruisance. We do know, from newspaper articles, of the physical violence occasionally wreaked upon defenseless women. The best way to overcome that danger is to deter the assailants from being in the country at all. And here the "tramp house" with worktest attached will be a potent local remedy. The State of Massachusetts in I905 passed a drastic tramp law, providing that ablebodied vagrants, whenever lodged by a community, shall be required to render reasonable work in return for food and lodging, which shall be adequate. The result in one year was as follows:

$\begin{array}{lrl}\text { In } 1905,89 \text { almshouses lodged } & 23,341 & \text { vagrants. } \\ \text { In 1906, 61 almshouses lodged } & 7,900 & \text { “ } \\ \text { In 1905, I7 towns lodged } & 2,711 & \text { " } \\ \text { In 1906, I7 towns lodged } & 254 & \text { “ }\end{array}$

Bringing history down to date, we find the comparative absence of tramps in Massachusetts at present to be the result of the rigid enforcement of the tramp law. "It is the opinion of tramp officer Barrett that most of the tramps who formerly infested Massachusetts in large numbers cross over the state as quickly as they can from Connecticut or New York to New Hampshire or Vermont. The state can readily be crossed at almost any point in a day's travel over the roads. Rather than take a chance of a term in a Massachusetts jail, the real tramps hurry across the state to a point where the law is not so thoroughly enforced." 1

The Massachusetts law further provides that if tramps are to be lodged at all, they shall not be lodged in the almshouses in association with the paupers. In short, the laws of the Bay State are well calculated to make it disagreeable to be a tramp, and the burden of my argument in this paper is that that is the point of view we must adopt in general.

${ }^{1}$ The Review, February, 1912. 
Is this uncharitable? In no sense. What are the facts? The tramp is of no use even to the moralist, for the latter has other horrible examples from which he can draw his lessons and examples. $\mathrm{He}$ is not useful to the labor agitator, for the honest unemployed are sufficiently numerous without the tramp. He is not useful to the charitable societies as cases, or to the hospitals. $\mathrm{He}$ is not useful to the prisons, for he is the least susceptible of reformation. To whom is he useful? Not even to himself, for he is a miserable outcast. Then why should we encourage his vice to get the better of his will by being indifferent to the tramp problem? If we are not to be indifferent, we can use but one of two methods, gentle persuasion and charitable help, or rigorous prosecution and drastic treatment. The gentle persuasion and the charitable help are, in my opinion, generally failures; if they are not, why have we not reduced vagrancy? Any one will be apt to say to-day that vagrancy is more widespread than five years ago. Gentle persuasion and charitable help are useful in individual cases, and the spirit of charity toward the fallen and the outcast should never cease out of the land, but we must interpret what we mean by the spirit of charity. To my mind real charity in the problem of the tramp evil is the reduction to the least possible point of bread lines; of free meals and lodgings given by missions, charity societies and prison associations; and the elimination of private or public lodging houses which give free lodging and meals without worktests, or their re-organization into worktest lodging houses. In short, charity in the case of vagrancy means cutting off every chance for the individual vagrant to find an excuse to continue his life of workshyness and parisitism.

This sounds perhaps harsh and hostile, and so it would be, did not my recommendations carry with them provision for constructive assistance to the vagrant, which I shall shortly mention. I cannot too strongly emphasize, however, the folly of looking with tolerance and even pity upon the gradual descent of the vagrant into entire uselessness, instead of performing, if necessary, a major operation upon him early, an operation which, while it will hurt and be drastic, will not endanger life or even reasonable comfort, and will make him literally "sit up and take notice" that life is not one wild ride from city to city and one long series of idle days and debauched nights. 
Returning now to our deterrent forces for the reduction of vagrancy, I would put next the great desirability, and even necessity, of having certain state officials to arrest and prosecute vagrants. The graphically designated "tramp officer" is such a one. The state constabulary of Pennsylvania are such. We must protect the rural communities from vicious wanderers of the highway. The village constable is no person to prosecute tramps. In the first place, it is not his business to be a patrolman, and secondly, the farmer who calls him in has to pay fees for the arrest that he makes, if the laws of other sections of the country are the same as those prevailing in the town in which my small farm is located. A mounted constabulary is a great desideratum. Foreign countries have such, and the vagrants and the beggar shun them.

In the next place, persistent effort should be made in all states to do away so far as possible by law with the short sentence and the idle jail. This is not easy. New York has for years sought to establish reasonable industries in the county penitentiaries, but those institutions are under county management, which means often stupid political indifference. So long as counties maintain winter resorts for idle tramps, they can obtain a houseful without publishing any prospectuses. How ridiculous that the very persons who moan and burst into denunciations about the burdens of tramps are often the very ones that show immovable indifference to the jail or penitentiary problem as a penological question, or as anything except a plum for the spoils system!

I have outlined certain reasons for the continuance of the tramp-evil in the country. In the city, which is not a subject for special discussion in this series on rural life, the lodging houses, the complacent five-cent charity-monger on the street, the "rescueand-advertise-results" missions, the municipal lodging houses without worktests, and the lack of co-operative efforts to deal with the vagrancy question on a large scale and with differentiation of function, are some reasons why we see fully as many vagrants now as we did some years ago. But that is another story.

What shall we do? Organize the national vagrancy committee. Get funds enough and a general secretary of sufficient caliber to engineer a number of movements along the lines mentioned above. The vagrancy business at present is often nobody's business. Its ramifications are so many and so far-reaching that 
the charity worker naturally spends his energy on problems more local, nearer home. If there is one problem that should be dealt with on a national basis, it is the tramp problem.

In some states the problem has been forced to the front. New York is fortunate in the group of social workers on public boards and in private organizations who have urged successfully in recent years not alone the tramp colony for habitual tramps and vagrants, but also the establishment of a farm colony for inebriates by the city of New York, and the removal of the city reformatory for misdemeanants from New York City into the country. To catch the tramp young; to cure him if possible of his drink habit; to impress upon him in a tramp colony that tramping is a thing the State of New York does not intend longer to ignore, such are some of the recent moves in the Empire state.

But, along constructive instead of deterrent lines, a national vagrancy committee must make active studies. Inevitably there must be developed in our country some comprehensive form of free employment bureaus, which will eliminate the excuse of vagrants that, being down and out, there is no ready chance for them to get employment again. To the statement that charitable societies already try to "bring the jobless man and the manless job" together, the answer may be made that the general effort to find employment for the unemployed should not have the appearance of charity.

In connection with the development of free employment agencies there should be lodgings at frequent intervals, that is, in contiguous cities and communities where the unemployed may eat and sleep, in return for work done. Never can we conscientiously prosecute the intentionally idle vagrant at all points until we establish a means of temporary employment for him that will remove the plausible excuse that he cannot find employment.

The "way-ticket" plan, adapted from the German identification card, will probably be long in coming into the United States. It is still repugnant to the great majority of citizens to consider being tabbed or "mugged" and numbered. Such measures have been advocated, but their realization is far off. We cannot expect to control the progress from city to city of the unemployed seeker for a job, as is done in Germany. What we can do is to follow the general lead of Massachusetts, and make the entertainment of 
the vagrant conditional upon separating such entertainment from that given to paupers, and in return for work.

Along sanitary lines, we can do something by cleaning up the low lodging houses, where the poorest and the most shiftless of the unemployed sleep and "hang-out." Slowly the rules and regulations for common lodging houses are being improved in many cities. The board of health of New York City has recently put in force a rather drastic series of rules and regulations for the government of common lodging houses, after having received the suggested rules in 1907 from two of the large charitable societies of the city, which had compiled them from the experience of many American and foreign cities.

A very tangible method of reducing vagrancy to some extent is rigorously to prosecute begging on the streets or in public places. Abroad the courts make a careful distinction between begging in localities where poor relief is obtainable and in places where it cannot readily be obtained. In our large cities, poor relief for the homeless is accessible, and there should be no toleration of the street mendicant. New York City has suffered for several years from an increased amount of mendicancy, due to the removal in 1906 of the mendicancy squad that had under Mr. Forbes rendered such excellent service to the city under the control of the Charity Organization Society. The street mendicant perverts the charitable impulse without which society cannot maintain its philanthropic work. In the country the beggar has a ground for his story of need, unless there be in the neighborhood a place where he can find shelter, food, and work.

As I have said before, I shall not attempt to indicate the causes of vagrancy. These are in general the same as the causes of poverty, plus, often, the strong desire to wander. The most effective check on vagrancy is the proper kind of education of the young during the years from ten to twenty. The schools, the home and the church must all do their part in preparing the youth for a reasonable, honest and efficient life. Child labor, illness, mental defectiveness, congestion of population, truancy, orphanage, inefficiency, low wages, overwork, industrial accidents, diseases of occupation, the temptations of crime, seasonal and irregular trades; all these causes, and many more, operate to produce the youthful tramp. When they gain possession, the railroad is ready at 
hand to bear the boy from his hated surroundings to the wide, wide world beyond the horizon, often a horizon of dismal walls, and sooty chimneys, and slovenly backyards.

Yes, we need a national committee to take up soberly and comprehensively the treatment of the problems of vagrancy. For nearly a half century responsible persons in our country have intermittently emphasized the seriousness of the problem. The time is surely ripe now to act. The so-called larger social movements are well under way. We have our consumers' leagues, our national child labor committee, our national committee for the study and prevention of tuberculosis, our national housing committee, our rational association of charity organization societies, and even our national prisoner's aid association. There remain for compreliensive national treatment the two leading causes of commitment to penal institutions: inebriety and vagrancy. These two offenses against society frequently overlap. Should not the next step, or one of the next steps, be the establishment of a national movement to reduce one or both of these great social evils? 